\title{
DEVELOPMENT AND VALIDATION OF NOVEL ULTRAVIOLET SPECTROPHOTOMETRIC METHOD FOR QUANTITATIVE ESTIMATION OF DALFAMPRIDINE IN BULK AND IN PHARMACEUTICAL FORMULATION
}

\author{
VAIBHAV S KHODKE*, GAME MD \\ Department of Quality Assurance, Vidyabharati College of Pharmacy, Amravati, Maharashtra, India. Email: vaibhavkhodke0@gmail.com \\ Received: 05 April 2019, Revised and Accepted: 30 May 2019
}

ABSTRACT

Objective: The objective of the present study is to develop ultraviolet (UV)-spectroscopic method using pure drug and tablet dosage form that consistently produces a drug with a minimal variation that adheres to quality criteria of purity, identity, and potency.

Methods: UV-spectrophotometric method has been developed using a solvent composed of methanol:water (30:70) as a diluent to determine the dalfampridine (DFP) content in bulk and pharmaceutical dosage form at predetermined $\lambda$ max of $262 \mathrm{~nm}$.

Results: It was proved linear in the range of $02-12 \mu \mathrm{g} / \mathrm{ml}$ and exhibited a good correlation coefficient $\left(\mathrm{r}^{2}=0.9915\right)$ and excellent mean recovery $(0.004136347 \%)$. This method was successfully applied to the determination of DFP content of marketed tablet Dalstep 10 mg (Sun Pharmaceutical Pvt. Ltd.) from India; the results were in good agreement with the label claims.

Conclusion: The method proved to be simple, accurate, precise, specific, robust, and less time consuming and can be applied for the determination of DFP in bulk and marketed formulation.

Keywords: Dalfampridine, Ultraviolet spectrophotometric, Method development, Validation.

(C) 2019 The Authors. Published by Innovare Academic Sciences Pvt Ltd. This is an open access article under the CC BY license (http://creativecommons. org/licenses/by/4. 0/) DOI: http://dx.doi.org/10.22159/ajpcr.2019.v12i7.33938

\section{INTRODUCTION}

Dalfampridine (DFP, Fig. 1) is an oral potassium channel blocker recently approved by the Food and Drug Administration for symptomatic treatment of multiple sclerosis. It acts at the central and peripheral nervous systems, enhances conduction in demyelinated axons, and improves walking ability. Chemically, it is 4-aminopyridine, $p$ aminopyridine, or fampridine. Literature survey reveals the clinical overview of DFP, pharmacokinetic analysis of extended-release tablets, development for symptomatic improvement and management in patients with multiple sclerosis, Phase 3 trial of extended-release oral drug, and its efficacy as a treatment to improve walking in patients with multiple sclerosis. Thus, at the moment, available literature only highlights therapeutic and pharmacological profile of drug but no published methods validated for its [1-3].

Several high-performance liquid chromatography (HPLC) assay methods have been reported for the determination of DFP. Literature survey revealed that various analytical methods such as high-performance thin-layer chromatography and reversed-phase-HPLC have been reported for the estimation in of DFP [4]. Recently, some ultraviolet (UV) spectrophotometric methods were also reported for estimating DFP using various solvents such as water, $0.1 \mathrm{M}$ hydrochloric acid, $100 \%$ methanol, or acetonitrile. In this study, efforts were made to develop a simple, easy, and economical UV spectrophotometric method using a diluent composed of water:methanol (70:30) for the determination of DFP in the raw materials as well as in the marketed dosage formulations. The developed method was optimized and validated as per the guidelines of the International Conference on Harmonization (ICH) and demonstrated excellent specificity, linearity, precision, and accuracy for DFP $[5,6]$.

\section{MATERIALS AND METHODS}

\section{Apparatus}

A Shimadzu UV-visible spectrophotometer (UV mini-1800, Shimadzu Corporation, Kyoto, Japan) was used for all absorbance measurements with matched quartz cells.
Materials

All chemicals and reagents were of analytical grade. DFP was provided by Rajesh Chemical Co. Pvt. Ltd., Mumbai, which was used as the reference standard. Pharmaceutical grade excipients were obtained from Pharmaceutical Technology Laboratory (Merck Chem. Ltd., Mumbai).

\section{Preparation of standard stock solutions}

Accurately weighed $10 \mathrm{mg}$ of DFP transferred to a $100 \mathrm{ml}$ volumetric flask. It was dissolved in methanol, and volume was made up to the mark with water as a solvent to obtain the final strength of $100 \mu \mathrm{g} / \mathrm{ml}$. Then, aliquots of standard stock solution were prepared by suitably diluting with the same solvent to get the final concentrations of $2,4,6$, 8,10 , and $12 \mu \mathrm{g} / \mathrm{ml}$.

Determination of absorption maximum ( $\lambda$ max)

$1 \mathrm{ml}$ of stock-II solution was taken in $10 \mathrm{ml}$ graduated tube aside for $5 \mathrm{~min}$. The solution was made up to $10 \mathrm{ml}$ with water. This gives $10 \mu \mathrm{g} / \mathrm{ml}$ solution of DFP and was scanned in the range of 400-200 nm to determine the absorption maximum for the drug.

\section{Method validation [5,6]}

The developed method was validated for precision and accuracy as per ICH guidelines for the following parameters.

\section{Precision}

Repeatability

The repeatability (precision of the instrument) was checked by measuring the absorbance of six determinations of $10 \mu \mathrm{g} / \mathrm{ml}$ solution, and percentage relative standard deviation (\%RSD) was calculated $[7,8]$.

Linearity and range

For linearity study, seven solutions at different concentrations $(2,4,6$, 8,10 , and $12 \mathrm{mg} / \mathrm{mL}$ ) were prepared using seven different aliquots, and 
the obtained data were used for the linearity calibration plot. Limit of detection (LOD) and limit of quantitation (LOQ) for the assay were also calculated [9].

Intraday precision (repeatability) and interday precision study (intermediate precision)

The pure drug was finely powdered, and the sample stock solution of $100 \mathrm{mg} / \mathrm{mL}$ was prepared following the same dilution pattern. Three different aliquots of dalfampridine were then diluted to $10 \mathrm{~mL}$ to obtain the concentrations of 10,20 , and $30 \mathrm{mg} / \mathrm{mL}$. This procedure was repeated in the following days $[10,11]$.

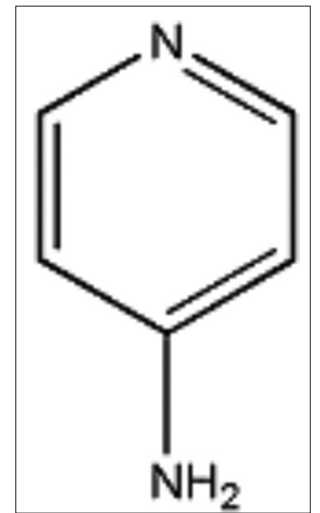

Fig. 1: Chemical structure of dalfampridine

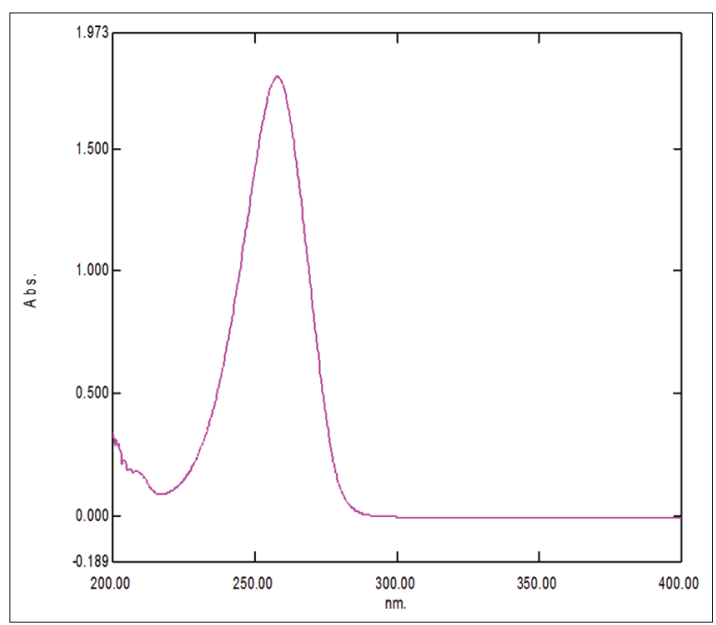

Fig. 2: Spectra of standard dalfampridine

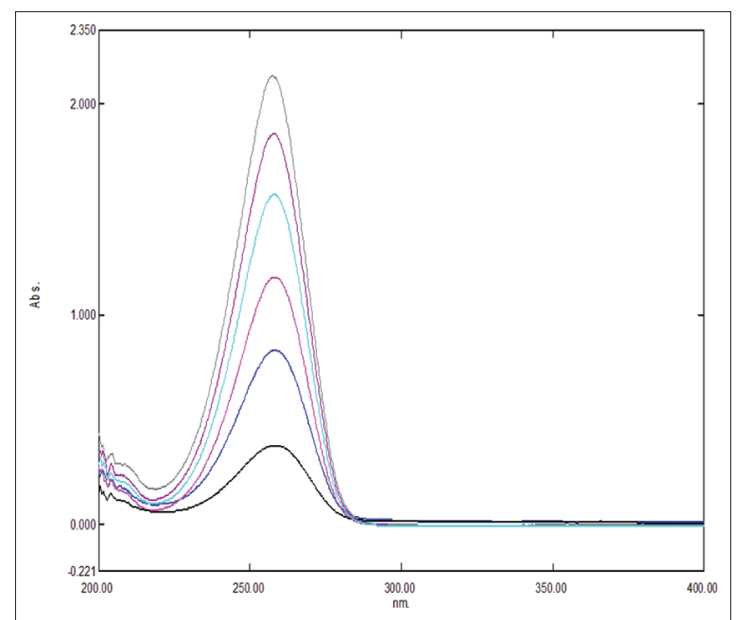

Fig. 3: Overlain spectra of dalfampridine
Accuracy

Accuracy for drug substance was determined on samples of drug solutions at varying concentration levels in the range of $80 \%-120 \%(10 \mu \mathrm{g} / \mathrm{ml}$, $20 \mu \mathrm{g} / \mathrm{ml}$, and $30 \mu \mathrm{g} / \mathrm{ml}$ ) by analyzing three levels of each sample as a batch in a single assay. The \% RSD was calculated at each level [12].

\section{Recovery study}

For drug product, 10 tablets were weighed, powdered, and estimation was carried out. Recovery studies were carried out by adding a known amount of standard drug to sample solution.

\section{Sensitivity}

The sensitivity of the proposed method was estimated in terms of LOD and limit of quantitation (LOQ). The LOD and LOQ were calculated as $\mathrm{LOD}=3.3(\mathrm{SD} / \mathrm{S})$ and $\mathrm{LOQ}=10(\mathrm{SD} / \mathrm{S})$, where SD is the residual standard deviation of the peak areas of the drug $(n=6)$ and $S$ is the slope of the line. Sensitivity was performed between 2 and $3 \mu \mathrm{g} / \mathrm{ml}$ for each spectroscopic method [13].

\section{Ruggedness [6]}

The ruggedness of the proposed methods was determined by analysis of aliquots from the homogenous slot by two analysts using the same operational and environmental conditions [14].

\section{Assay of Dalstep $10 \mathrm{mg}$ (DFP) tablets}

Assay of the content of DFP in selected marketed brands analyzed using the newly developed and validated method. $0.6 \mathrm{~mL}$ of dalfampridine was diluted to $10 \mathrm{~mL}$ to obtain $6 \mathrm{mg} / \mathrm{mL}$ DFP reference standard solution. Sample solutions of each tablet $(6 \mathrm{mg} / \mathrm{mL})$ were also prepared and assayed for the content of DFP against the reference standard [15].

The content of DFP in the marketed brands was determined using with solvent $(10 \mu \mathrm{g} / \mathrm{mL})$.

1. Standard calibration curve

2. Repeatability.

\section{RESULTS}

The new analytical method was developed, optimized, validated, and applied for the quantitative analysis of pure drug and marketed tablets.

Table 1: Standard calibration curve of dalfampridine at $262 \mathrm{~nm}$

\begin{tabular}{ll}
\hline Concentration & Absorbance \\
\hline 0 & 0 \\
2 & 0.379 \\
4 & 0.830 \\
6 & 1.177 \\
8 & 1.569 \\
10 & 1.859 \\
12 & 2.136 \\
Slope & 0.175 \\
Intercept & 0.094 \\
$\mathrm{R}^{2}$ & 0.9915 \\
\hline
\end{tabular}

Table 2: Repeatability of dalfampridine at $262 \mathrm{~nm}$

\begin{tabular}{lll}
\hline S.No & Concentration & Absorbance \\
\hline 1 & 10 & 1.859 \\
2 & 10 & 1.855 \\
3 & 10 & 1.801 \\
4 & 10 & 1.827 \\
5 & 10 & 1.869 \\
6 & 10 & 1.830 \\
Mean & - & 1.84016667 \\
SD & - & 0.02536467 \\
$\%$ RSD & - & 1.37838982 \\
\hline SD: Standard deviation \% RSD: Percentage relative standard deviation
\end{tabular}




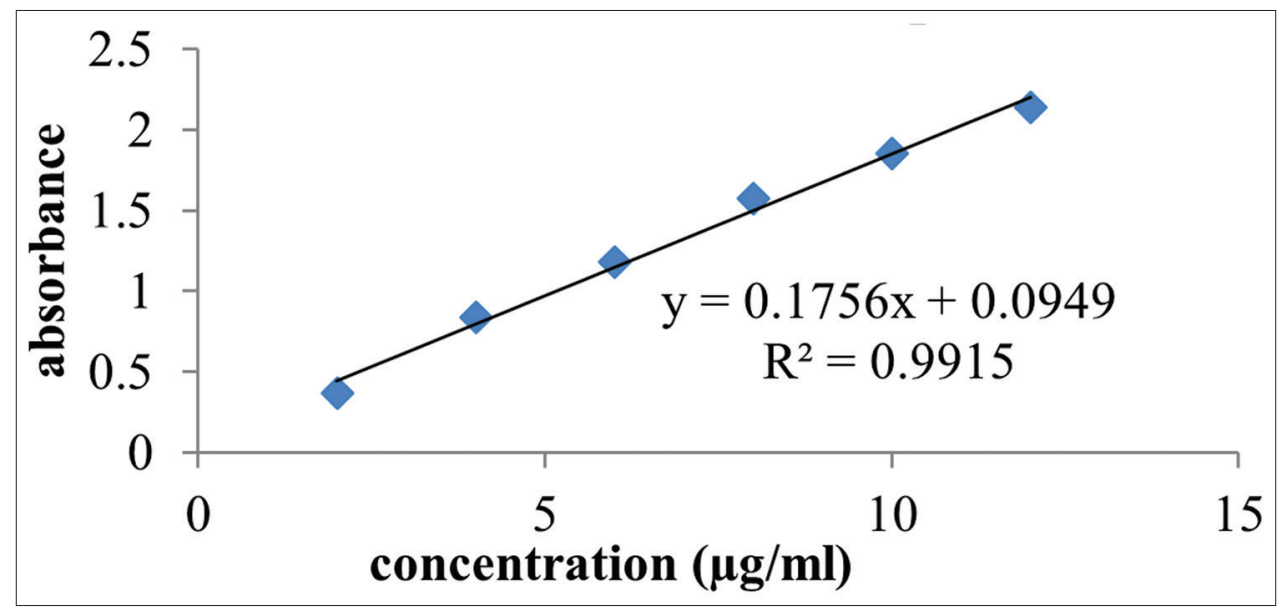

Fig. 4: Standard calibration curve of dalfampridine

Table 3: Intraday: Precision data for dalfampridine at $262 \mathrm{~nm}$

\begin{tabular}{|c|c|c|c|c|c|}
\hline \multirow[t]{2}{*}{ Concentration (ug/ml) } & \multicolumn{2}{|c|}{ Intraday } & \multirow[t]{2}{*}{ CV } & \multirow[t]{2}{*}{$\pm \mathrm{SD}$} & \multirow[t]{2}{*}{$\%$ RSD } \\
\hline & $\mathbf{M}$ & $\mathbf{E}$ & & & \\
\hline 10 & 1.798 & 1.786 & 0.00473509 & 0.0084853 & 0.00473509 \\
\hline 20 & 2.476 & 2.475 & 0.00028564 & 0.0007071 & 0.00028564 \\
\hline 30 & 2.782 & 2.778 & 0.00101742 & 0.0028284 & 0.00101742 \\
\hline
\end{tabular}

$\mathrm{n}=3$ : Number of replicates, SD: Standard deviation, \% RSD: Percentage relative standard deviation, CV: Coefficient variation

Table 4: Interday: Precision data for dalfampridine at $262 \mathrm{~nm}$

\begin{tabular}{|c|c|c|c|c|c|c|}
\hline \multirow[t]{2}{*}{ Concentration (ug/ml) } & \multicolumn{3}{|c|}{ Interday } & \multirow[t]{2}{*}{ CV } & \multirow[t]{2}{*}{$\pm \mathrm{SD}$} & \multirow[t]{2}{*}{$\%$ RSD } \\
\hline & Day 1 & Day 2 & Day 3 & & & \\
\hline 10 & 1.798 & 1.786 & 1.751 & 0.01399 & 0.02475 & 0.01066563 \\
\hline 20 & 2.476 & 2.41 & 2.398 & 0.00353 & 0.00849 & 0.00327417 \\
\hline 30 & 2.782 & 2.743 & 2.74 & 0.00077 & 0.00212 & 0.00076987 \\
\hline
\end{tabular}

$\mathrm{n}=3$ : Number of replicates, SD: Standard deviation, \% RSD: Percentage relative standard deviation, CV: Coefficient variation

Method development and optimization

DFP is soluble in an aqueous medium and freely soluble in organic solvents such as methanol and acetonitrile. During the development phase, the use of methanol with water as the diluent resulted in a preferable outcome in UV analysis. The solvent composition was optimized to water (70):methanol (30). The predetermined wavelength of maximum absorption (lmax) was $262 \mathrm{~nm}$

\section{Absorption spectrum of DFP}

The absorption maximum of $262 \mathrm{~nm}$ observed from the absorption spectrum was selected as the wavelength for spectrophotometric determinations. The absorption spectrum is shown in Fig. 2. Selection of analytical concentration range and linearity given in Table 1, Figs. 3 and 4.

\section{Method validation}

Linearity and range

The calibration curve obtained was evaluated by its correlation coefficient. The absorbance of the samples in the range of $02-12.0 \mu \mathrm{g} / \mathrm{mL}$ was linear with a correlation coefficient $\left(\mathrm{R}^{2}\right)>0.999$. The LOD and LOQ were calculated as $11.88 \mu \mathrm{g} / \mathrm{mL}$ and $36.02 \mu \mathrm{g} / \mathrm{mL}$, respectively.
1. Precision
2. Accuracy
3. Recovery
4. Ruggedness
5. LOD

i. $\quad$ LOD $=3.3 \times$ standard deviation of $y$-intercept/slope of the calibration curve $=11.88 \mathrm{ug} / \mathrm{ml}$

6. Limit of quantitation
Table 5: Determination of accuracy (percentage recovery)

\begin{tabular}{|c|c|c|c|}
\hline \multirow[t]{2}{*}{ Spiking (\%) } & \multicolumn{3}{|l|}{ Dalfampridine } \\
\hline & $\begin{array}{l}\text { Amount } \\
\text { of drug } \\
\text { added }(\mu \mathrm{g} / \mathrm{ml})\end{array}$ & $\begin{array}{l}\text { Amount of the } \\
\text { drug found } \\
(\mu \mathrm{g} / \mathrm{ml})\end{array}$ & $\begin{array}{l}\text { Percentage } \\
\text { recovery }\end{array}$ \\
\hline 0 & 0 & 0 & 0 \\
\hline 80 & 10 & 9.98 & 99.8 \\
\hline 100 & 20 & 19.26 & 96.30 \\
\hline 120 & 30 & 29.98 & 99.33 \\
\hline Mean & & & 98.4766667 \\
\hline SD & & & 1.89964032 \\
\hline$\%$ RSD & & & 0.01929026 \\
\hline
\end{tabular}

$\mathrm{n}=3$ : Number of replicates, SD: Standard deviation, \% RSD: Percentage relative standard deviation

i. $L O Q=10 \times$ standard deviation of $y$-intercept/slope of the calibration curve $=36.02 \mathrm{ug} / \mathrm{ml}$

Intraday and interday precision

The intraday and interday precision study (Tables 3 and 4) of the developed method confirmed adequate sample stability and method reliability where all the RSDs were $0.00028564 \%-0.00327417 \%$.

\section{Accuracy}

The accuracy of the method was assessed by studies at three different levels, i.e., $80 \%, 100 \%$, and $120 \%$. The values of standard deviation 
Table 6: Recovery data for dalfampridine drug product (tablet)

\begin{tabular}{lllll}
\hline S.No & $\begin{array}{l}\text { Amount of } \\
\text { standard }(\mu \mathrm{g} / \mathbf{m l})\end{array}$ & $\begin{array}{l}\text { Amount of } \\
\text { sample }(\mu \mathrm{g} / \mathbf{m l})\end{array}$ & $\begin{array}{l}\text { Total concentration } \\
(\mu \mathrm{g} / \mathbf{m l})\end{array}$ & $\begin{array}{l}\text { Total concentration } \\
\text { found }(\mu \mathrm{g} / \mathbf{m l})\end{array}$ \\
\hline 1 & 6 & 5.2 & 11.2 & 11.1 \\
2 & 6 & 6 & 12 & 11.90 \\
3 & 6 & 6.8 & 12.8 & 12.78 \\
Mean & 99.36666667 & & & 99.10 \\
SD & 0.411015004 & & & 99.16 \\
CV & 0.004136347 & & & \\
\% RSD & 0.004136347 & & \\
\hline
\end{tabular}

Table 7: Ruggedness data for dalfampridine at $262 \mathrm{~nm}$ $(50 \mu \mathrm{g} / \mathrm{ml})$

\begin{tabular}{llll}
\hline Instrument 1 & Instrument $\mathbf{2}$ & Result of t-test* $^{*}$ & Inference \\
\hline 3.013 & 3.007 & 0.4694005 & $\begin{array}{l}\text { No significant } \\
\text { difference }\end{array}$ \\
3.020 & 3.027 & & \\
3.012 & 3.010 & & \\
\hline $\mathrm{n}=3:$ Number of replicates & &
\end{tabular}

Table 8: Linear regression analysis of the calibration curve with respective absorptivity value

\begin{tabular}{ll}
\hline Parameters & Dalfampridine \\
\hline Recovery (\%) & \\
80 & 99.8 \\
100 & 96.30 \\
120 & 99.33 \\
Precision (CV) & \\
Intraday (n=3) & 0.019103 \\
Interday (n=3) & 0.00353 \\
Regression equation slope & $\mathrm{y}=0.175 \times 0.094$ \\
Coefficient of correlation ( ${ }^{2}$ ) & $R^{2}=0.9915$ \\
Ruggedness (t-test) & \\
Instrument 1 & 0.4694005 \\
Instrument 2 & \\
LOD & $11.88 \mathrm{ug} / \mathrm{ml}$ \\
LOQ & $36.02 \mathrm{ug} / \mathrm{ml}$ \\
\hline CV: Coefficient variation, LOD: Limit of detection, LOQ: Limit of quantification
\end{tabular}

Table 9: Assay of Dalstep

\begin{tabular}{llll}
\hline Formulation & $\begin{array}{l}\text { Labeled } \\
\text { amount (mg) }\end{array}$ & $\begin{array}{l}\text { Amount } \\
\text { obtained (mg) }\end{array}$ & $\begin{array}{l}\text { Percentage } \\
\text { recovered }\end{array}$ \\
\hline Dalstep tablet & 10 & 9.87 & 98.7 \\
\hline
\end{tabular}

were satisfactory, and the recovery studies were close to $100 \%$. The $\%$ RSD value $\leq 2$ indicates the accuracy of the method.

\section{Recovery (marketed tab)}

Results within the range of $99.10 \%-99.84 \%$ ensure an accurate method (Table 6) as well as indicate non-interference with the excipients of the formulation. Content of DFP in marketed brands Dalstep determined by the proposed method (Table 9) was in good agreement with the label claims and was in the range of $99.10 \%-99.84 \%$ with the RSD values of $0.004136347 \%$, respectively.

\section{DISCUSSION}

Analytical method development and validation of DFP formulation were the basic aim of the current research. A novel, simple, precise, and specific UV-spectrophotometric method was developed and validated. DFP showed maximum absorbance at $262 \mathrm{~nm}$. The drug was derivatized in methanol:water solution. Beer-Lambert law was obeyed at a concentration range of $2-12(\mu \mathrm{g} / \mathrm{ml})$. A linearity curve was calibrated by concentration versus absorbance. The regression equation of curve was calculated as $\mathrm{Y}=0.1756 \mathrm{x}+0.0949$ and correlation coefficient $\mathrm{r}^{2}=0.9915$. The accuracy was determined by recovery study, and the overall percentage recovery was found to be $98.4766667 \%$. The $\%$ RSD of precision was found to be $\angle 2$. The LOD and LOQ were calculated as $11.88 \mathrm{ug} / \mathrm{ml}$ and $36.02 \mathrm{ug} / \mathrm{ml}$, respectively. The developed method was validated in terms of linearity, accuracy, precision, the LOD, the limit of quantification, and ruggedness as per ICH guidelines. The developed and validated method was applied for the estimation of DFP in bulk and tablet dosage form. The method was successfully applied in quality control analysis of DFP in pharmaceutical formulation.

\section{CONCLUSION}

The developed UV spectrophotometric method for the quantitative estimation of DFP pure drug and in tablets was precise and accurate and can be used for routine analysis of bulk drug and formulations. The applicability of the method for biological samples is to be studied.

\section{ACKNOWLEDGMENTS}

The author would like to thank Rajesh Chemical Co. Pvt. Ltd., Mumbai, India, for providing the gift samples of dalfampridine. We are highly grateful to Dr. Mrs. M. D. Game, Vidyabharati College of Pharmacy, Camp, Amravati, for providing the necessary facilities to carry out this research work.

\section{AUTHORS' CONTRIBUTIONS}

The first author (V. K.) initiated and conducted the research work under the guidance second author (M. G.).

\section{CONFLICTS OF INTEREST}

The authors declare that there are no conflicts of interest regarding the publication of this paper.

\section{REFERENCES}

1. Dunn J, Blight A. Dalfampridine: A brief review of its mechanism of action and efficacy as a treatment to improve walking in patients with multiple sclerosis. Curr Med Res Opin 2011;27:1415-23.

2. Indian Pharmacopoeia Commission. Indian Pharmacopoeia. Vol. I. New Delhi: The Controller of Publication; 2014. p. 527.

3. Willard-Hobart H, Lynne LM Jr., John AD, Frank AS Jr. Instrumental Methods of Analysis. New Delhi: CBS Publishers and Distributors; 1988. p. 1-12, 580-10, 614-52.

4. Munson JW. In Pharmaceutical Analysis. Modern Methods. Mumbai: International Medical Book, Distributors; 2001. p. 28-32.

5. Chatwal GR, Anand SK. Instrumental Methods of Chemical Analysis. $5^{\text {th }}$ ed. New Delhi: Himalaya Publishing House; 2002. p. 566-87, 624-39.

6. Haque SK, Ahmad A. Development and validation of analytical method for quantification of acetic acid content in amlodipine besylate. Int $\mathrm{J}$ Pharm Pharm Sci 2019;11:8-11.

7. Swetha G, Kumar KP, Sirisha K. New validated method development for the estimation of sulfamethoxazole and trimethoprim in bulk form 
by visible spectroscopy. Int J Pharm Pharm Sci 2018;10:50-7.

8. Wasnik RN. Method development and validation of antineoplastic drug-imatinib by uv-spectroscopy. Indo Am J Pharm 2018;4:362-9.

9. Dashora K, Singh D, Saraf S. Validation-the essential quality assurance tool for pharmaceutical industries. Pharm Process Validation 2005;3:45-7.

10. Kaur M, Bhardwaj P, Kaur B, Sharma A, Karu C, Kumar R, et al. Development and validation of a novel stability indicating uv-spectrophotometric method for estimation of febuxostat in bulk and pharmaceutical formulation (tablets). Pharm Methods 2018;9:23-8.

11. Moharana A, Banerjee M. Development and validation of UV spectrophotometric method for the determination of mesalamine in bulk and tablet formulation. Int J Pharm Pharm Sci 2011:3:19-21.

12. Behera S, Ghanty S. UV-visible spectrophotometric method development and validation of assay of paracetamol tablet formulation. J Anal Bioanal Tech 2012;3:6.

13. Available from: https://www.drugs.com/monograph/dalfampridine. html.

14. Available from: https://www.pubchem.ncbi.nlm.nih.gov/compound/4aminopyridine

15. International Conference On Harmonization (Ich) Of Technical Requirements For The Registration Of Pharmaceuticals For Human Use. Ich-Q2(R1). Geneva: Validation of Analytical Procedures Methodology; 1996. p. 1-8. 